\title{
Plankton development in Lake Jonsvatn, Norway, after introduction of Mysis relicta: a long-term study
}

\author{
Jan Ivar Koksvik ${ }^{1, *}$, Helge Reinertsen ${ }^{2}$, Jarl Koksvik ${ }^{1}$ \\ ${ }^{1}$ Museum of Natural History and Archaeology, Section of Natural History, and ${ }^{2}$ Department of Biology, Norwegian \\ University of Science and Technology, 7491 Trondheim, Norway
}

\begin{abstract}
Quantitative sampling of phyto- and zooplankton has been carried out for $25 \mathrm{yr}$ in Lake Jonsvatn, Norway, in order to assess changes after the introduction of Mysis relicta. In Lille Jonsvatn, the outlet basin, the cladoceran populations collapsed $7 \mathrm{yr}$ after the mysid introduction. The mean cladoceran biomass was reduced by 95 to $99 \%$ for a decade before Bosmina longispina, Holopedium gibberum and Daphnia galeata developed new populations. B. longispina and H. gibberum almost disappeared again after a few years, while $D$. galeata was replaced by $D$. longispina, which unexpectedly maintained a relatively dense population in the presence of high mysid abundance. Rotifers declined significantly in Lille Jonsvatn after the mysid establishment, whereas copepod biomass did not change. Phytoplankton biomass increased during the first years after the cladoceran collapse, but declined later to levels lower than in pre-mysid years. The changes were probably a combined effect of reduced nutrient loads and grazing pressure. In the main basin, Store Jonsvatn, there were no detectable effects on the zooplankton community during the first 10 to $15 \mathrm{yr}$ after the introduction, in spite of development to common densities of mysids within $8 \mathrm{yr}$. Over time, cladocerans decreased significantly, however, and mean biomass for the last $5 \mathrm{yr}$ showed a $60 \%$ reduction compared with the first 10 yr. No significant long-term changes were detected in copepods, rotifers or phytoplankton biomass in Store Jonsvatn. Differences in temperature, stratification, light transmission and depth may partly explain the different plankton development in the 2 basins.
\end{abstract}

KEY WORDS: Mysis relicta $\cdot$ Long-term study $\cdot$ Phytoplankton biomass $\cdot$ Zooplankton biomass

\section{INTRODUCTION}

From 1954 to 1975 the opossum shrimp Mysis relicta was introduced in many lakes in Scandinavia in order to serve as a supplementary food for fish. In Sweden, introductions took place in 61 lakes (Fürst et al. 1984), and in Norway in 9 lakes. The Norwegian introductions all took place between 1968 and 1974, and through downstream dispersal $M$. relicta established populations in 6 additional lakes. The introductions in Scandinavia were specifically performed in lakes that were regulated for hydroelectric power production, where production of fish food organisms was reduced because of large fluctuations in water level. Before and concurrently with the Scandinavian introductions, the species was also introduced to a large number of North American lakes (Lasenby et al. 1986, Nesler \& Bergersen 1991)

Mysis relicta was assumed to feed mainly on dead organic matter from the bottom in the deeper parts of the lakes, and through extensive diurnal vertical migrations it would act as an energy elevator by serving as fish food in the upper water layers (Fürst et al. 1984). The dietary habits of $M$. relicta turned out to be quite complex, however. Grossnickle (1982) showed in an overview that $M$. relicta is capable of both filterfeeding and raptorial feeding, eating phytoplankton, zooplankton, benthos, detritus and sediments. More re- 
cent studies have added nuanced information to the omnivorous feeding habits of $M$. relicta (Branstrator et al. 2000, Johannsson et al. 2001, Lasenby \& Shi 2004, Ikonen et al. 2005, Scharf \& Koschel 2005). After introductions both in North America and Scandinavia, it gradually became evident that $M$. relicta had the ability to reduce zooplankton abundance and change species composition through its predatory behavior (Lasenby \& Langford 1973, Threlkeld et al. 1980, Kinsten \& Olsén 1981, Lasenby et al. 1986, Nero \& Sprules 1986a, Langeland et al. 1991, Spencer et al. 1999). In many of the target lakes, $M$. relicta turned out to be an effective competitor with planktivorous fish for zooplankton prey. Because of its diurnal migratory behaviour, M. relicta avoided, to a large extent, predation by pelagic fish that search visually for food (Næsje et al. 1991).

The knowledge of effects from mysid introductions in Scandinavia is mainly restricted to oligotrophic regulated lakes (Fürst et al. 1984, Langeland et al. 1991). Lake Jonsvatn is unregulated and consists of basins that differ with respect to morphometry and water quality. Some studies indicate that increased lake productivity may reduce the adverse effects of Mysis relicta on the plankton populations (Nesler \& Bergersen 1991). In the present study, special attention was given to the basin called Lille Jonsvatn, which had a higher nutrient level than typical lakes with introduced mysids in Norway, and was therefore hypothesized to be less negatively affected.

The introduction of Mysis relicta to Lake Jonsvatn was due to a water diversion tunnel from the neighbouring Lake Selbusjøen where mysid introduction took place in 1973. Most probably, M. relicta was swept into Lake Jonsvatn when the tunnel was opened for the first time in 1978. The tunnel is normally closed. An investigation in 1981 showed that M. relicta was by then established in Store Jonsvatn. As water flows from Store Jonsvatn through Lille Jonsvatn into the outlet river, M. relicta most likely developed populations almost simultaneously in the 2 basins.

The present study deals with the long-term development of phyto- and zooplankton in Lake Jonsvatn after introduction of Mysis relicta. It is based on data from 1980 to 2006. The Lake Jonsvatn study represents the longest continuous data series in Scandinavia on the development of the plankton communities after introduction of M. relicta. It has been classified by the Norwegian Research Council as especially valuable to maintain.

\section{MATERIALS AND METHODS}

Study site. Lake Jonsvatn $\left(63^{\circ} 22^{\prime} \mathrm{N}, 10^{\circ} 37^{\prime} \mathrm{E}\right)$ is located $150 \mathrm{~m}$ above sea level in central Norway (Fig. 1). It is an oligotrophic lake that serves as a drinking water

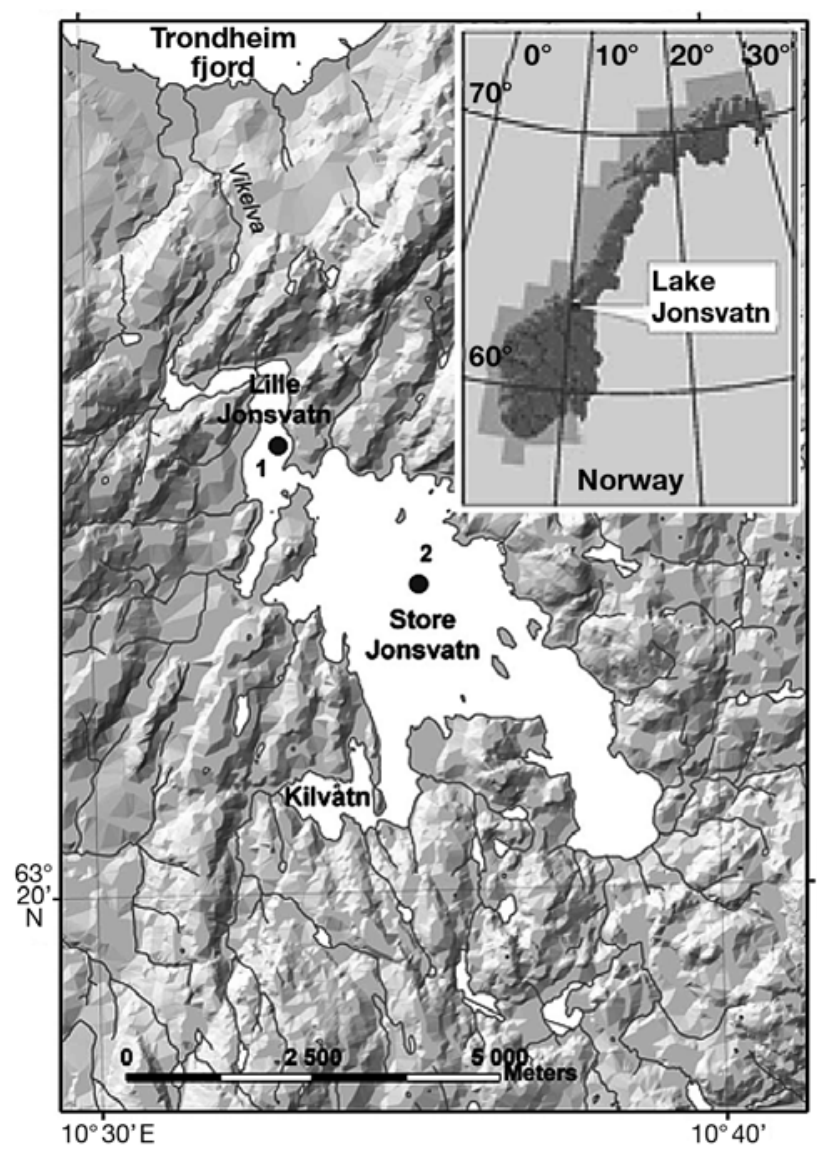

Fig. 1. Lake Jonsvatn, Norway, and sampling stations in Lille Jonsvatn (1) and Store Jonsvatn (2)

reservoir for the city of Trondheim (160 000 inhabitants). The surface area is $15 \mathrm{~km}^{2}$, maximum depth $97 \mathrm{~m}$ and mean depth $37 \mathrm{~m}$. In addition to the main basin-Store Jonsvatn $\left(12.4 \mathrm{~km}^{2}\right)$ - the lake has 2 nearly disconnected basins, Lille Jonsvatn $\left(1.6 \mathrm{~km}^{2}\right)$ and Kilvatn $\left(0.8 \mathrm{~km}^{2}\right)$. There are narrow sounds with depths of 1 to $3 \mathrm{~m}$ between the main lake and the embayments. The maximum depth in Lille Jonsvatn is $37 \mathrm{~m}$ and in Kilvatn $34 \mathrm{~m}$.

The chemical data of Lille Jonsvatn and Store Jonsvath are characteristic for oligotrophic conditions (Table 1). However, both total P (Mann-Whitney $U$-test,

Table 1. Physical and chemical characteristics (range of annual means) of surface waters (0 to $5 \mathrm{~m}$ ) of Lille Jonsvatn and Store Jonsvatn between 1989 and 2006. Data provided by the Environmental Division, Municipality of Trondheim

\begin{tabular}{|lcc|}
\hline & \multicolumn{2}{c|}{ Annual mean range } \\
& Lille Jonsvatn & Store Jonsvatn \\
\hline $\mathrm{pH}$ & $7.1-7.5$ & $7.2-7.4$ \\
Conductivity $\left(\mu \mathrm{S} \mathrm{cm}^{-1}\right)$ & $64-74$ & $51-64$ \\
Total $\mathrm{P}\left({\left.\mu \mathrm{g} \mathrm{l}^{-1}\right)}^{-1}\right)$ & $4.6-10.6$ & $2.4-7.4$ \\
Total $\mathrm{N}\left(\mu \mathrm{g} \mathrm{l}^{-1}\right)$ & $311-428$ & $297-419$ \\
\hline
\end{tabular}


$\mathrm{p}=0.001)$ and total $\mathrm{N}(\mathrm{p}=0.045)$ are significantly higher in Lille Jonsvatn. The $\mathrm{P}$ content (average of mixed samples from 0 to $5 \mathrm{~m}$ from all seasons) has significantly decreased in both Store Jonsvatn and Lille Jonsvatn during the investigation period (Fig. 2).

Epilimnetic summer temperatures normally reach 15 to $20^{\circ} \mathrm{C}$ in both basins, whereas temperatures at $20 \mathrm{~m}$ depth reach 5 to $7^{\circ} \mathrm{C}$ (Fig. 3). Temperatures closer to the bottom stay at 4 to $6^{\circ} \mathrm{C}$ throughout the summer. Due to a higher degree of wind exposure, the thermocline lies deeper in Store Jonsvatn than in Lille Jonsvatn (Fig. 3). Secchi depth observations show that light transmission is highest in Store Jonsvatn (Table 2).

The drainage area mainly consists of coniferous forests and some cultivated farmland, especially around Lille Jonsvatn. Restrictions on farming and development have been imposed since the early 1990s in order to reduce the runoff of nutrients from human activities.

Arctic char Salvelinus alpinus, brown trout Salmo trutta, northern pike Esox lucius and three-spined stickleback Gasterosteus aculeatus are the only fish species that occur in Lake Jonsvatn. Brown trout, northern pike and three-spined stickleback occurred only in the littoral zone in Store Jonsvatn, whereas Arctic char utilized both the littoral and the pelagic
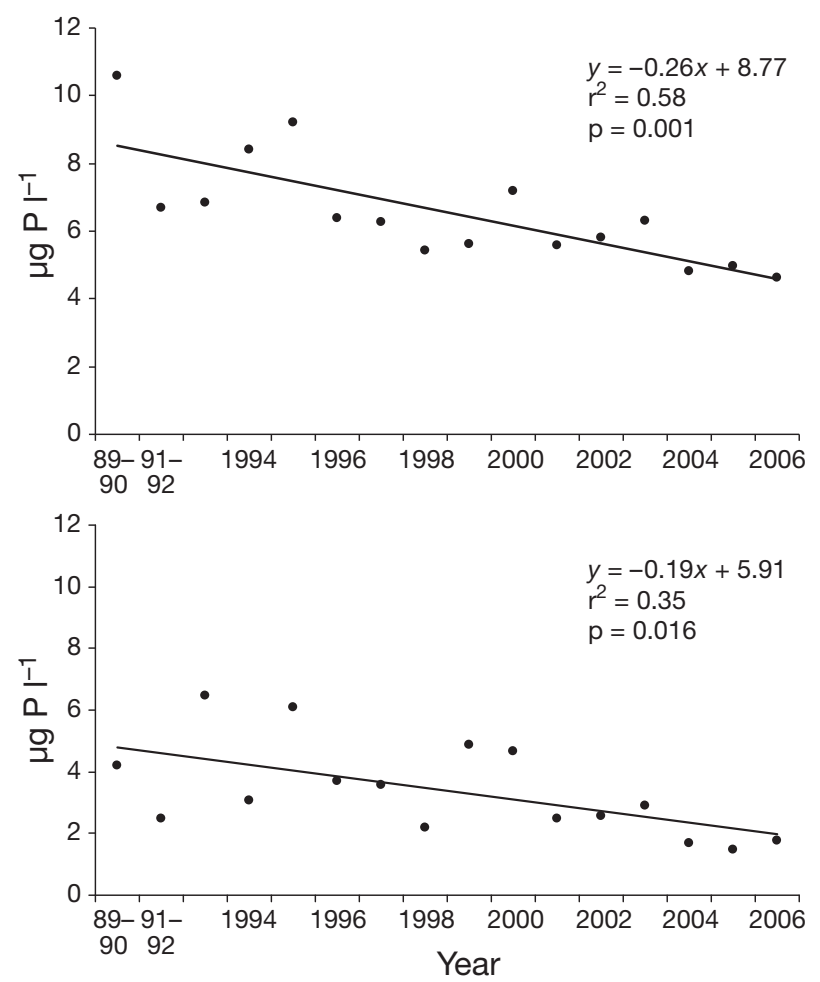

Fig. 2. Regression of total $\mathrm{P}\left(\mu \mathrm{g} \mathrm{l}^{-1}\right)$ versus sampling year in Lille Jonsvatn (top) and Store Jonsvatn (bottom). Only pooled data were available for the years 1989-1990 and 1991-1992. Data provided by the Environmental Division, Municipality of Trondheim

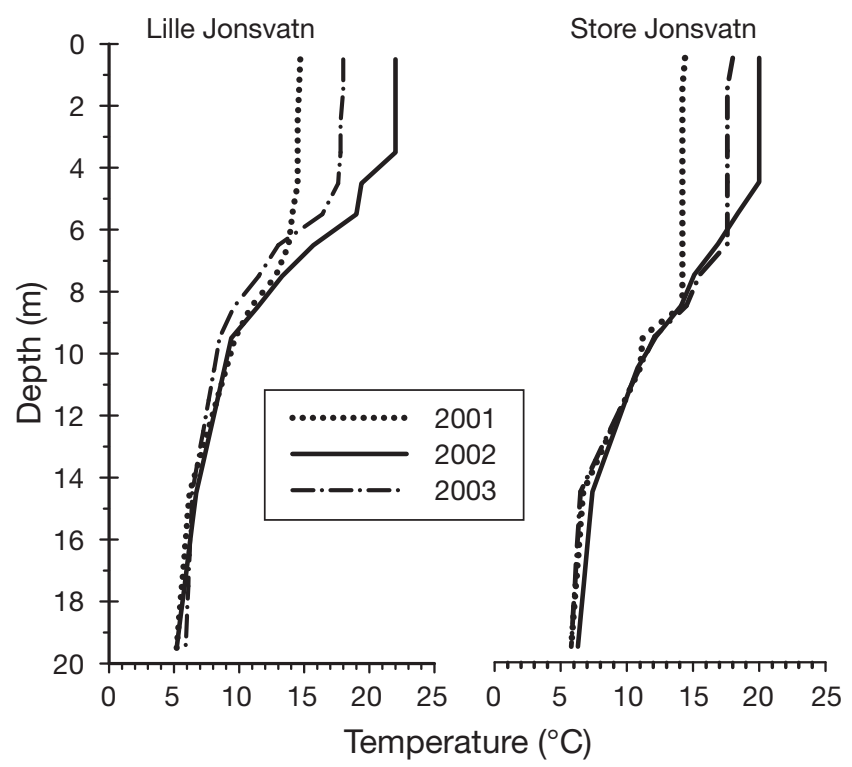

Fig. 3. Temperature profiles in Lille Jonsvatn and Store Jonsvatn. Early August data from 3 subsequent years with different summer temperatures

zones (Næsje et al. 1991). An investigation of the fish populations in Lille Jonsvatn in 1999 gave an extremely low yield of Arctic char and brown trout both in the littoral zone, along the bottom in deeper areas and in the pelagic zone, whereas northern pike were exclusively caught along the bottom (Koksvik 2000). We have observed three-spined stickleback only along the shore. In Store Jonsvatn, the catch per unit effort (CPUE, $24 \mathrm{~h}$ fishing, 0 to $10 \mathrm{~m}$ depth) in floating gillnets was $<1$ to 5 Arctic char per $100 \mathrm{~m}^{2}$ net area in the pelagic zone (Næsje et al. 1991), while the corresponding yield (0 to $6 \mathrm{~m}$ depth) was 0.4 Arctic char and 0.2 brown trout in Lille Jonsvath (Koksvik 2000). According to local fishermen, the populations of Arctic char and brown trout have been very small for several decades in Lille Jonsvatn.

Table 2. Secchi depths (m) in Lille Jonsvatn and Store Jonsvatn. Data are June-September averages for 2001 to 2006

\begin{tabular}{|lcc|}
\hline \multirow{2}{*}{ Year } & \multicolumn{2}{c|}{ Secchi depth (m) } \\
& Lille Jonsvatn & Store Jonsvatn \\
\hline 2001 & 4.3 & 5.5 \\
2002 & 5.5 & 6.7 \\
2003 & 5.4 & 6.8 \\
2004 & 5.0 & 6.8 \\
2005 & 5.3 & 6.9 \\
2006 & 5.3 & 6.2 \\
Mean & 5.1 & 6.5 \\
\hline
\end{tabular}


Plankton sampling. Plankton was sampled at Stns 1 \& 2 (Fig. 1). Zooplankton was sampled with a $1 \mathrm{~m}$ long plexiglass tube sampler. Each sample contained $5 \mathrm{l}$ of water. A vertical column extending from 0 to $20 \mathrm{~m}$ depth was consistently sampled every $1 \mathrm{~m}$. Samples from $5 \mathrm{~m}$ layers were mixed and treated as one sample. Additional zooplankton sampling was carried out by vertical net hauls (90 $\mu \mathrm{m}$ mesh) to secure sufficient material for length measurements and biomass calculations. The net was hauled vertically from $20 \mathrm{~m}$ to the surface. Zooplankton samples were preserved with Lugol's solution in the field and later transferred to $70 \%$ ethanol for permanent storage.

All zooplankton samples were identified to species and enumerated. Counts were carried out on the total samples or subsamples containing $1 / 10$ of the total sample. On each sampling date, length measurements were made on 30 to 50 individuals of each cladoceran species from each station. Copepods were distinguished to the instar level when counted. Biomass calculations for cladocerans and copepods (with fixed individual weights for different instars) were made according to length/weight regressions from Bottrell et al. (1976) and Langeland (1982). Rotifer biomass was calculated using individual weights given in Bottrell et al. (1976). The zooplankton material has been incorporated into the collections of the Museum of Natural History and Archaeology at the Norwegian University of Science and Technology.

Integrated phytoplankton samples from 0 to 5 and 5 to $10 \mathrm{~m}$ were collected in Lille and Store Jonsvatn with a plexiglass water sampler (volume $=1.6$ l). Phytoplankton samples of $200 \mathrm{ml}$ were taken from the pooled samples and preserved with Lugol's solution. The samples were analysed according to the Utermöhl settling technique. For each sample a minimum of 200 cells or colonies was counted and identified to genus or species. Volume of counted cells was calculated using simple geometric models, and the biovolume was converted to wet weight assuming a specific gravity of $1.0 \mathrm{mg} \mathrm{mm} \mathrm{m}^{-3}$. Wet weights for algal groups and total algal biomass are given as means of biomass of the 2 integrated samples, i.e. mean biomass of 0 to $10 \mathrm{~m}$.

Mysis relicta was sampled by vertical net hauls in Lille Jonsvatn in 1996 and 1999-2006. The net had a frame opening of $1 \mathrm{~m}^{2}$, a mesh size of $500 \mu \mathrm{m}$ and was equipped with a lead weight at its mouth, sinking upside down before being hauled up again vertically. Each sample thus consisted of 2 vertical hauls, between $1 \mathrm{~m}$ above the bottom $(30 \mathrm{~m})$ and the surface. Sampling was performed on the plankton station in the dark in October-November, which is within the period when $M$. relicta is most abundant in the pelagic zone in Lake Jonsvatn (Næesje et al. 1991, 2003); 3 replicate hauls were performed on every sampling occasion.
The present study did not include sampling of mysids in Store Jonsvatn.

In 1980, zooplankton was sampled on 3 occasions within the June-September period, and in 1983 to 1987 , monthly from June to September. From 1988 onwards, zooplankton samples were collected 6 times per year (monthly sampling in June and September, twice monthly in July and August). Both plankton stations were always sampled simultaneously. Phytoplankton was sampled at the same stations and dates as zooplankton in Lille Jonsvatn in 1980, 1983, 1985, 1986 and 1988-2006, and in Store Jonsvatn in 1980, 1983, 1985, 1987, 1994 and 1996-2006. Biomass means of both phytoplankton and zooplankton are given as estimated averages of all samples in the particular year. The change in sampling intensity from 1988 onwards might have led to a slight increase of mean zooplankton biomass and for some years a decrease in mean phytoplankton biomass, but not to an extent that has influenced the trends of development in either group.

\section{RESULTS}

\section{Zooplankton}

In Lille Jonsvatn, a mean biomass (June-September) of 1100 to $1650 \mathrm{mg} \mathrm{m}^{-2}$ (dry weight) was recorded until 1985, when a dramatic decline took place (Fig. 4). The cladoceran biomass was then reduced to less than $5 \%$ of the mean for 1980-1984, and in 1986-1987 the cladocerans had become virtually extinct (mean biomass $=2$ and $9 \mathrm{mg} \mathrm{m}^{-2}$, respectively). Extremely low biomasses of cladocerans were recorded for $10 \mathrm{yr}$. The previously dominant species, Bosmina longispina, had a mean biomass in 1985-1994 that was less than 1\% compared with the estimates for years prior to 1985 , and the other common species, Daphnia galeata and Holopedium gibberum, were irregularly found in low numbers throughout this period. In 1995, a moderate recovery of $B$. longispina was recorded $\left(140 \mathrm{mg} \mathrm{m}^{-2}\right)$. In 1996, the mean biomass of $B$. longispina increased to almost $600 \mathrm{mg} \mathrm{m}^{-2}$, and D. galeata and H. gibberum also developed populations with mean biomasses of 170 and $320 \mathrm{mg} \mathrm{m}^{-2}$, respectively (Fig. 5). Total cladoceran biomass was again on the level recorded before the collapse in 1985. After 1996, the mean biomass of cladocerans has varied between 230 and $540 \mathrm{mg} \mathrm{m}^{-2}$. Since 1998, B. longispina has been virtually absent, and $H$. gibberum has also been recorded in extremely low numbers except for a moderate abundance in 2000. The daphnids continued to increase until 2000, and have afterwards fluctuated in abundance. The highest daphnid biomass (540 $\mathrm{mg} \mathrm{m}^{-2}$ ) in the entire investigation period was recorded in 2006. D. galeata 


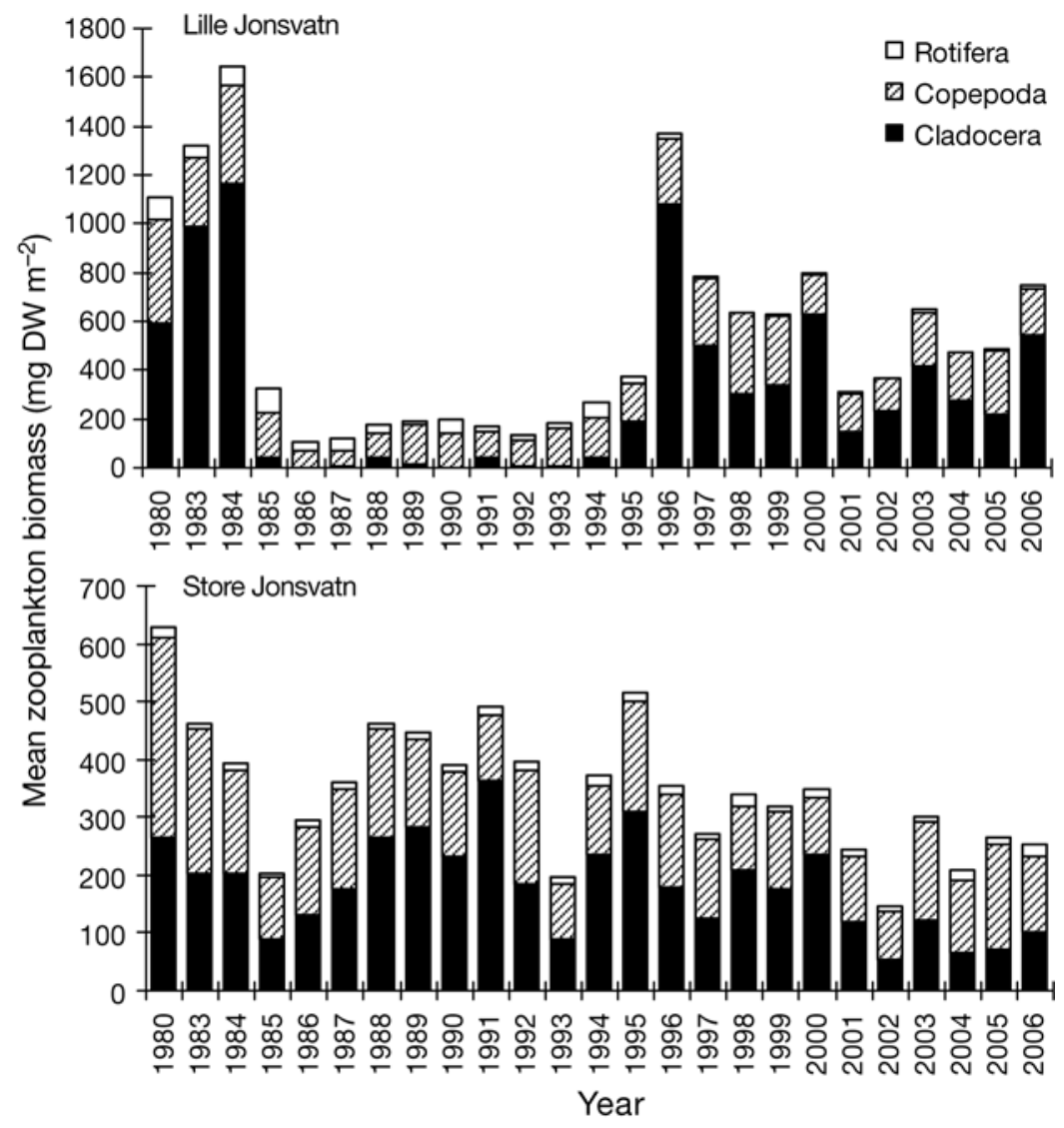

Fig. 4. Mean June-September biomass (mg dry weight $\mathrm{m}^{-2}$ over $20 \mathrm{~m}$ ) of zooplankton in Lille Jonsvatn (top) and Store Jonsvatn (bottom) in the period 1980-2006. The lake was not sampled in 1981 and 1982

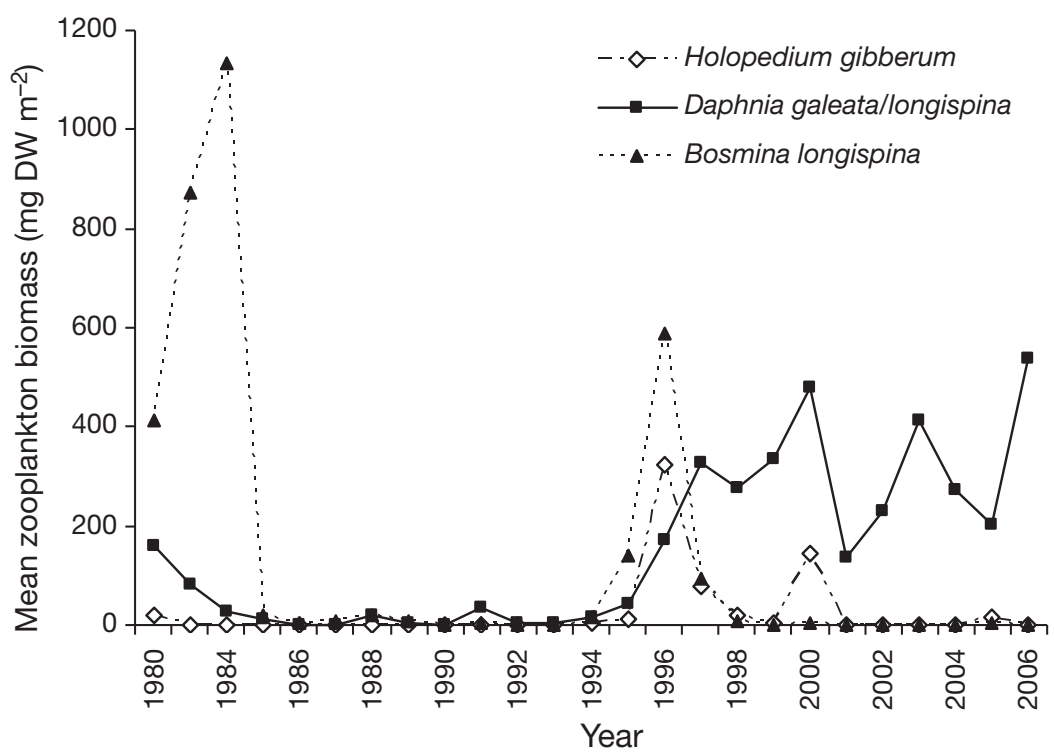

Fig. 5. Holopedium gibberum, Daphnia galeata/longispina and Bosmina longispina. Development of zooplankton biomass ( $\mathrm{mg}$ dry weight $\mathrm{m}^{-2}$ over $20 \mathrm{~m}$ ) in Lille Jonsvatn over the period 1980-2006. The lake was not sampled in 1981 and 1982 was the only daphnid in the samples until 1998, when Daphnia longispina turned up, and became the dominant species from 1999 onwards. The biomass of $D$. galeata after the appearance of $D$. longispina was extremely low ( $<1$ to $6 \mathrm{mg} \mathrm{m}^{-2}$ in 2004-2006).

Total biomass of copepods also declined in Lille Jonsvatn after 1984 (Fig. 4), but not to the same extent as cladocerans. Mean biomass for the years 1985-1995 was $129 \pm 12$ (SE) $\mathrm{mg} \mathrm{m}^{-2}$, compared to $369 \pm 43 \mathrm{mg} \mathrm{m}^{-2}$ for the years prior to 1985 ; copepod biomass was significantly different in the 2 periods (MannWhitney $U$-test, $\mathrm{p}<0.01)$. The biomass reduction in copepods was mainly due to the dominant species Cyclops scutifer. The other copepods in question, Heterocope appendiculata, Arctodiaptomus laticeps and Mesocyclops leuckarti, showed no clear trend in biomass between 1985 and 1995. In 1996, copepods developed the highest biomass since 1984, and a level of 270 to $330 \mathrm{mg} \mathrm{m}^{-2}$ was maintained until 2000. Mean biomass for the period 1996-2006 was $224 \pm 18 \mathrm{mg} \mathrm{m}^{-2}$, which is $73 \%$ higher than for 1985-1995. The difference in biomasses between the 2 periods was highly significant $(\mathrm{p}<0.001)$. C. scutifer was the dominant species through the entire period. Acanthodiaptomus denticornis turned up as a new copepod species in 1999, and maintained the second highest biomass for all but one year afterwards, closely followed by $A$. laticeps.

Rotifer biomass was relatively high (55 to $95 \mathrm{mg} \mathrm{m}^{-2}$ ) in 1980-1984 and dominated by the colony forming Conochilus sp. that made up 50 to $75 \%$ of the total. Asplanchna priodonta, Polyarthra sp., Keratella cochlearis and Kellicottia longispina also made up a significant share of the biomass. After 1984, Conochilus sp. biomass dropped to almost zero for a $10 \mathrm{yr}$ period; after that, it varied at very low levels. Kellicottia longispina was also strongly decimated after 1984. From 1996 on, all species had very low biomass, and total rotifer biomass averaged 2 to $12 \mathrm{mg} \mathrm{m}^{-2}$ in 1997-2006. Keratella cochlearis had the highest biomass most years during this period. The development of rotifers through the entire investigation period fits an exponential regression (Fig. 6).

In Store Jonsvatn, zooplankton biomass decreased between 1980 and 1985, but then increased again until 1988 (Fig. 4). The changes were caused by the cladocerans Bosmina 


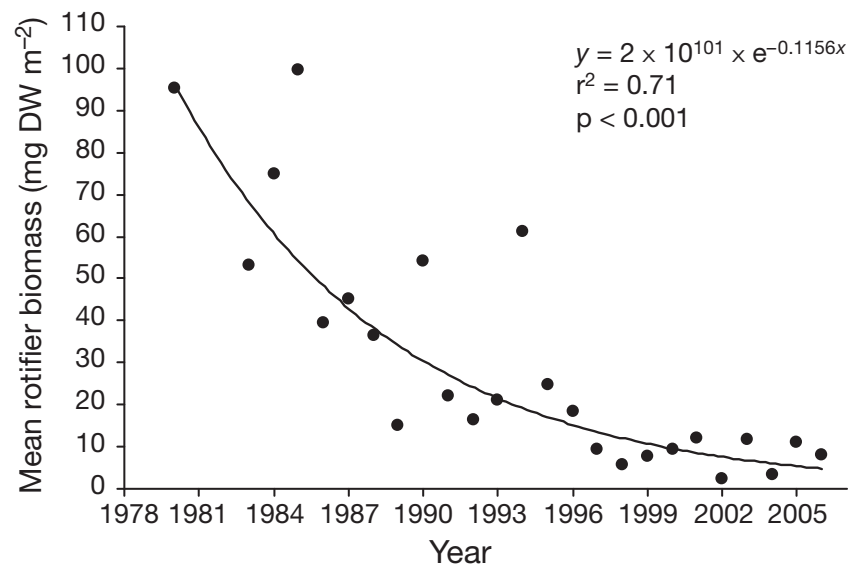

Fig. 6. Regression of mean rotifer biomass (mg dry weight $\mathrm{m}^{-2}$ over $20 \mathrm{~m}$ ) versus sampling year (1980-2006) in Lille Jonsvatn. The lake was not sampled in 1981 and 1982

longispina and Daphnia galeata and the copepods Cyclops scutifer and Heterocope appendiculata. After 1988 there was a long-term decrease in cladoceran biomass (Fig. 7). The change fits a linear regression. The most pronounced decline was found in $B$. longispina and D. galeata. Mean biomass of cladocerans in 1998-2006 was $128 \pm 22 \mathrm{mg} \mathrm{m}^{-2}$ compared to $226 \pm$ $27 \mathrm{mg} \mathrm{m}^{-2}$ in 1988-1997. The difference in biomass was highly significant (Mann-Whitney $U$-test, $\mathrm{p}<0.01$ ), and 4 of the last 5 years studied represent the lowest biomasses of Cladocera in the entire investigation period.

A corresponding decline in copepod biomass was not detected in Store Jonsvatn. Mean biomass in 19982006 was $127 \pm 11 \mathrm{mg} \mathrm{m}^{-2}$ compared to $150 \pm 11 \mathrm{mg}$ $\mathrm{m}^{-2}$ in 1988-1997 (not significant; Mann-Whitney $U$-test, $\mathrm{p}=0.14)$. Cyclops scutifer was the dominant species in most years, constituting a mean of $55 \%$ of the total copepod biomass in 1988-2006. Heterocope

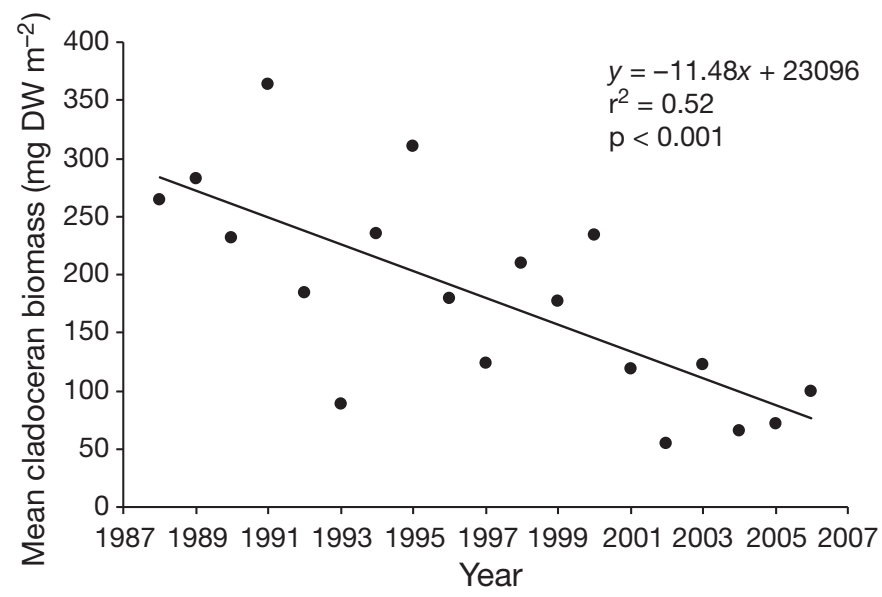

Fig. 7. Regression of mean cladoceran biomass (mg dry weight $\mathrm{m}^{-2}$ over $20 \mathrm{~m}$ ) versus sampling year (1988-2006) in Store Jonsvatn appendiculata and Arctodiaptomus laticeps were present with moderate abundance in all years and did not show any significant trend in biomass. As in Lille Jonsvatn, Acanthodiaptomus denticornis was recorded as a new species in Store Jonsvatn in 1999, and was found in very low numbers most years afterwards.

Rotifer biomass was low in Store Jonsvatn throughout the entire investigation period. Yearly means varied between 7 and $20 \mathrm{mg} \mathrm{m}^{-2}$ and there was no long-term trend in biomass change. Conochilus sp. was the dominant rotifer most years and constituted an average of $61 \%$ of the total rotifer biomass. The next most abundant rotifers were Polyarthra sp. with $20 \%$ and Asplanchna priodonta with $8 \%$ of the total rotifer biomass.

\section{Phytoplankton}

In Lille Jonsvatn, the maximum annual peak biomass reached 2020 and $2150 \mathrm{mg} \mathrm{m}^{-3}$ (wet weight) in 1989 and 1994, respectively, and values $>1000 \mathrm{mg} \mathrm{m}^{-3}$ were recorded in 1980-1989 (Fig. 8). Except for 1994, the spring peak biomass gradually declined from 1989 onwards, to maximum values near $300 \mathrm{mg} \mathrm{m}^{-3}$ at the end of the investigated period. Diatoms constituted 60 to $90 \%$ of the recorded maximum biomass in 1980-1990 and 1994, and Asterionella formosa and Synedra spp. were the dominant species.

The mean June-September biomass showed a significant decline from 1000 to $1100 \mathrm{mg} \mathrm{m}^{-3}$ in 1985, 1986 and 1989 to about $200 \mathrm{mg} \mathrm{m}^{-3}$ at the end of the investigation (Fig. 9). Diatom biomass declined from $293 \mathrm{mg}$ $\mathrm{m}^{-3}$ or $41 \%$ of the mean total biomass in 1985-1995 to $73 \mathrm{mg} \mathrm{m}^{-3}$ or $23 \%$ of the mean biomass in 1995-2006. The diatoms made up a significantly lower proportion of the total algal biomass in the latter period (MannWhitney $U$-test, $\mathrm{p}=0.02$ ). Asterionella formosa and Synedra spp. were also recorded in the summer samples, and in the later phase of the investigation Rhizosolenia eriensis, $R$. longiseta and a small Cyclotella species (5 $\mu \mathrm{m}$ diameter) became more frequent diatom species.

The biomass of cryptophytes, the second most important algal group, changed from a mean of $170 \mathrm{mg} \mathrm{m}^{-3}$ in 1985-1995 to $110 \mathrm{mg} \mathrm{m}^{-3}$ in 1996-2006. However, their proportion of the total biomass increased significantly (Mann-Whitney $U$-test, $\mathrm{p}=0.007$ ), from about 23 to $36 \%$ from the former to the latter period, respectively, and cryptophytes constituted in 1996-2006 up to $60 \%$ of the biomass during summer and autumn samples. Rhodomonas lacustris was the most frequent cryptophyte species.

Chrysophytes constituted close to $24 \%$ of the mean biomass in all investigated years. Dinobryon sociale var. americanum was the dominant species during the 


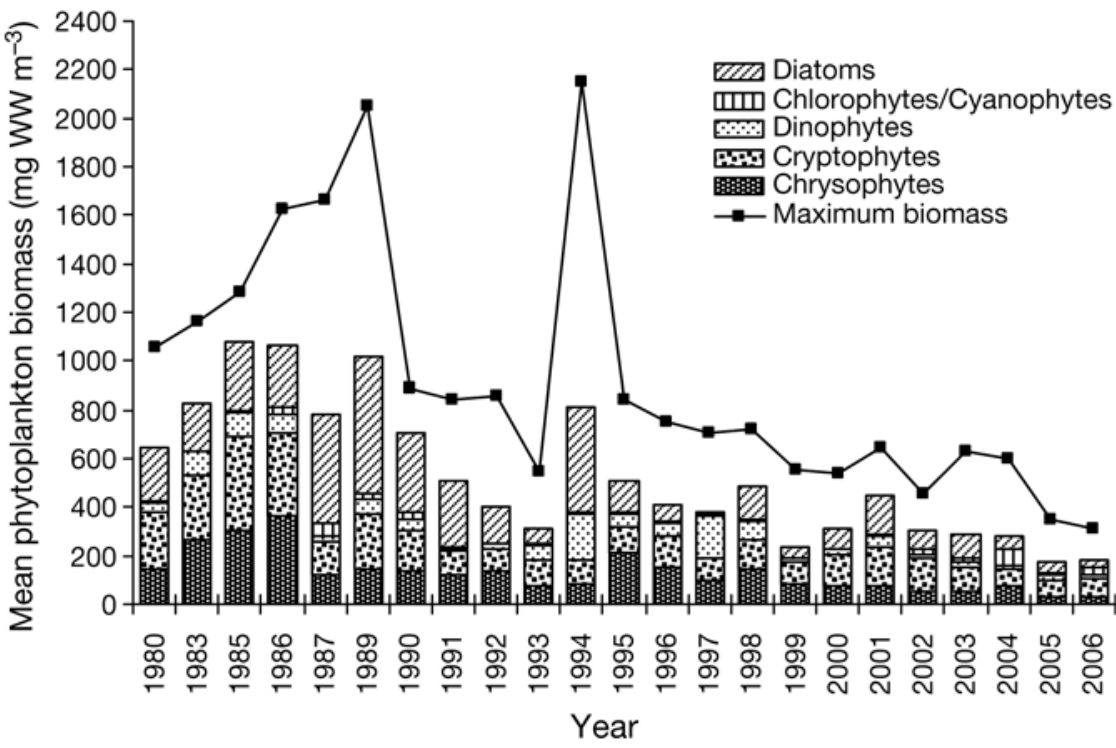

Fig. 8. Mean (mg wet weight $\mathrm{m}^{-3}$ over $10 \mathrm{~m}$ ) and maximum biomasses of phytoplankton groups in Lille Jonsvatn over the period 1980-2006. There are no data from 1981, 1982, 1984 or 1988

spring period and was also frequently recorded in the summer and autumn periods together with other Dinobryon species and individuals of Bitrichia chodati, Pseudochephyrion entchii, Chrysoikos skujai, Mallomonas crassisquamma, M. akrokomos and Chrysochromulina parva.

Three dinophyte species, Gymnodinium lacustre, Peridinium inconspicuum and Ceratium hirundinella, constituted about $10 \%$ of the total biomass in all years. Chlorophytes, usually Scenedesmus sp., Monoraphidium dybowskii, and M. griffithii, were recorded in low numbers. However, from 2002 on, gelatinous chlorophytes such as Sphaerocystis schroeteri and Willea irregularis were also included in the biomass estimates,

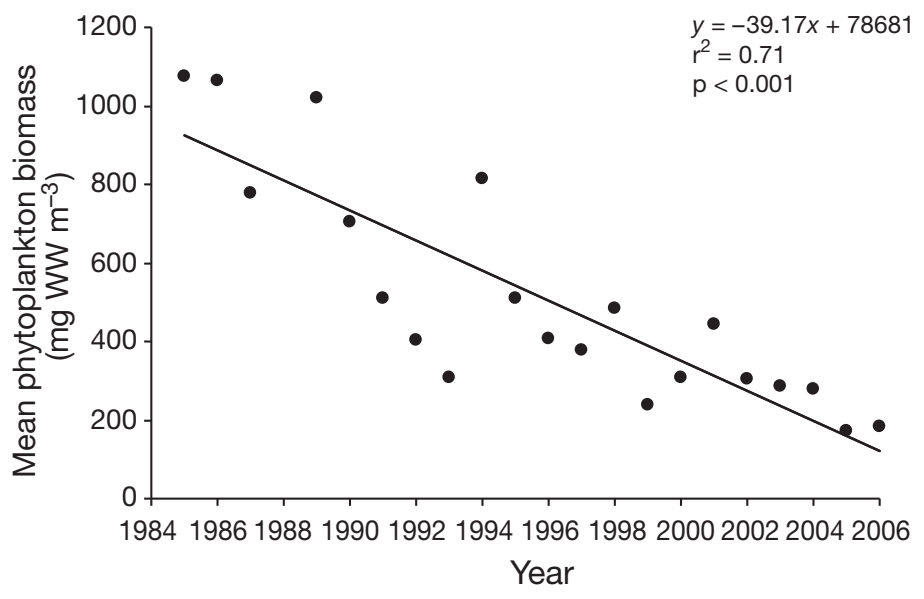

Fig. 9. Regression of mean phytoplankton biomass (mg wet weight $\mathrm{m}^{-3}$ over $10 \mathrm{~m}$ ) versus sampling year (1985-2006) in Lille Jonsvatn. There are no data from 1988 and a maximum biomass was recorded in August 2004, when gelatinous chlorophytes constituted $22 \%$ of the total biomass. The colony-forming cyanophyte Coelosphaerium kuetzingianum was recorded in the late summer samples from 1996, and it was sufficiently abundant to be included in the biomass estimates from 2003 onwards. In 2004 this species constituted close to $60 \%$ of the recorded biomass in August samples. However, on an annual (JuneSeptember) basis the species never exceeded $12 \%$ of the biomass, and for the investigated period cyanophytes did not exceed $1 \%$ of the total biomass.

In Store Jonsvatn, a maximum phytoplankton biomass of 450 to $500 \mathrm{mg} \mathrm{m}^{-3}$ was recorded in June 2001 and 2002, and diatoms constituted 30 and $45 \%$ of the biomass, respectively. The highest mean seasonal biomass, 370 and $270 \mathrm{mg}$ $\mathrm{m}^{-3}$, were recorded in the same years. In all other years, mean seasonal biomasses varied from 130 to $230 \mathrm{mg} \mathrm{m}^{-3}$, and no specific trend in biomass development was recorded during the investigated period. The mean biomass for 1980-2006 was $190 \mathrm{mg}$ $\mathrm{m}^{-3}$, or about one-fourth of the mean biomass recorded for Lille Jonsvatn in the same period. However, in 2005 and 2006 the mean June-September biomass was similar in the 2 lakes.

Cryptophytes and chrysophytes each constituted about $30 \%$ of the mean June-September biomass in Store Jonsvatn, whereas the biomass shares of diatoms and dinophytes were close to 19 and $16 \%$, respectively. Chlorophytes accounted for $3 \%$ of this biomass. The taxa mentioned for Lille Jonsvatn were also the most frequent ones in Store Jonsvatn, except for gelatinous chlorophytes and cyanophytes that were present in very low numbers and not included in the biomass estimates in the latter basin.

\section{Phytoplankton-zooplankton relationships}

Biomass relationships between phytoplankton (0 to $10 \mathrm{~m}$ ) and herbivorous zooplankton (0 to $20 \mathrm{~m}$ ) have changed significantly in Lille Jonsvatn (Fig. 10). In the first years of the investigation, 1980 and 1983, the mean biomass of herbivorous zooplankton was larger than that of phytoplankton (1.6 and 1.4 times, respectively). This situation changed to an inverse relationship after 1984, with a phytoplankton biomass that was 4 to 12 times larger than that of zooplankton in 1986-1990. From 1996 onwards, the biomass of herbi- 


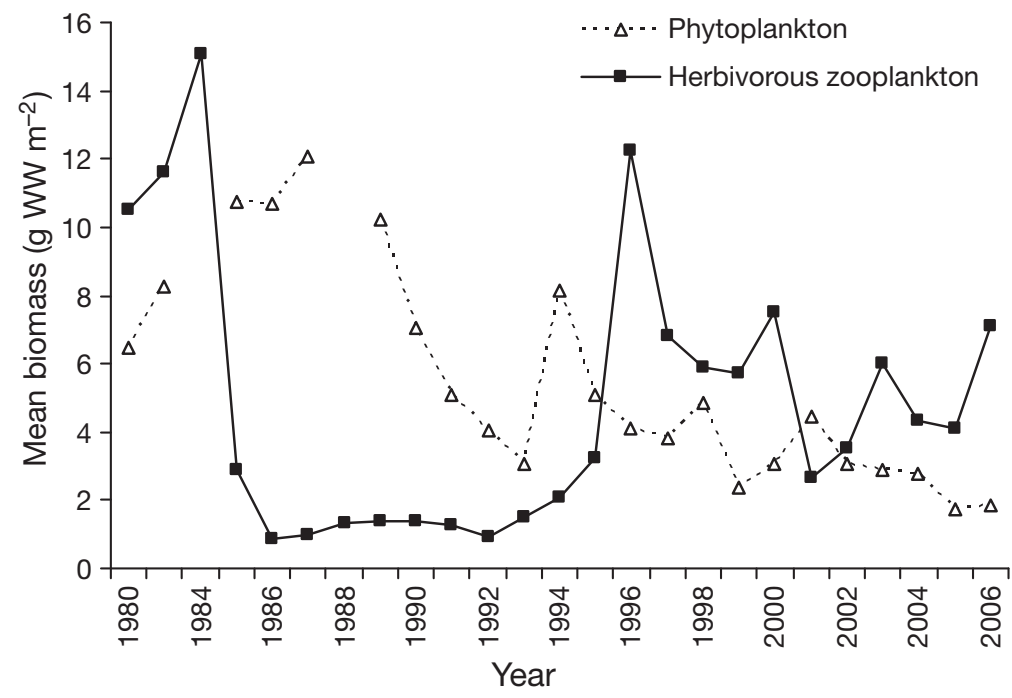

Fig. 10. Comparison of phytoplankton and herbivorous zooplankton biomass ( $g$ wet weight $\mathrm{m}^{-2}$ ) development in Lille Jonsvatn from 1980 to 2006. There are no data from 1981 or 1982 and only zooplankton data from 1984 and 1988

vorous zooplankton was on average 2.2 times higher than that of phytoplankton (except for 2001) for the period 1996-2006. In Store Jonsvatn, the mean biomass of herbivorous zooplankton was on average 1.8 times higher than that of phytoplankton in all years, except for 2001 and 2002.

\section{Mysis relicta}

Mysid data from Lille Jonsvatn in 1996 and yearly from 1999 to 2006 indicate 2.5 to 4.5 times higher abundance in 2003-2006 compared to 2000-2002 and 1996 (Fig. 11). The highest abundance was recorded in 2003 with 252 ind. $\mathrm{m}^{-2}$. In 1999, Mysis relicta was very scarce, with an abundance of only 3 ind. $\mathrm{m}^{-2}$. The first attempt to collect mysids in Store Jonsvatn was in

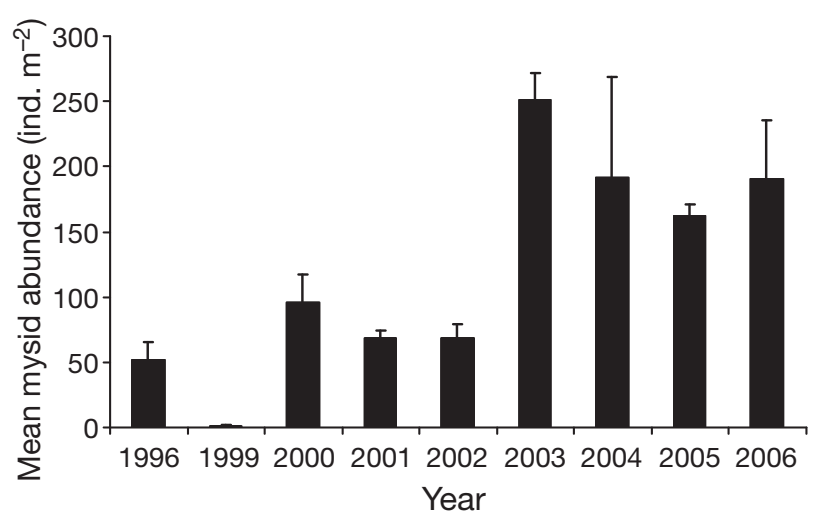

Fig. 11. Mysis relicta. Abundance (ind. $\mathrm{m}^{-2}$; mean $\pm \mathrm{SD}$ ) in Lille Jonsvatn in 1996 and 1999-2006
November 1981, when the mean abundance was estimated at 2.7 ind. $\mathrm{m}^{-2}$ in vertical hauls from 50 to $0 \mathrm{~m}$ (Koksvik et al. 1991). Næsje et al. (1991) recorded 50 to 110 ind. $\mathrm{m}^{-2}$ in Store Jonsvatn in 1986-1987 (August-December samples), and in 2000, the average of 3 vertical hauls (50 to $0 \mathrm{~m}$ ) in November was 31 ind. $\mathrm{m}^{-2}$ (J. I. Koksvik unpubl. data).

\section{DISCUSSION}

The results of the present long-term study reveal large differences in the plankton development in 2 basins of Lake Jonsvatn after introduction of Mysis relicta. In Lille Jonsvatn, the cladoceran populations collapsed about $7 \mathrm{yr}$ after the introduction that likely took place in 1978 in another basin of the lake, about $6 \mathrm{~km}$ from Lille Jonsvatn. Bosmina longispina was the strongly dominating cladoceran in Lille Jonsvatn before the collapse, followed by Daphnia galeata. The preference for cladocerans in the diet of Mysis spp. is well documented (Lasenby \& Langford 1973, Richards et al. 1975, Kinsten \& Olsén 1981, Langeland 1981, 1988, Bowers and Vanderploeg 1982). In Lake Tahoe, the dominant zooplankters Bosmina and 2 species of Daphnia virtually disappeared after the introduction of $M$. diluviana (formerly M. relicta) (Richards et al. 1975), and Bosmina and Daphnia were the preferred prey in Flathead Lake (Spencer et al. 1999). In Lake Selbusjøen, the source lake for mysids in Lake Jonsvaten, cladocerans were reduced to a very low biomass 5 to 6 yr after the introduction of $M$. relicta in 1973. The mysids had then developed an abundance of 200 to 600 ind. $\mathrm{m}^{-2}$ based on vertical haul samples. B. longispina, Holopedium gibberum and $D$. longispina were the most severely decimated cladoceran species (Langeland 1981, Langeland et al. 1991).

In another lake in the same region, Lake Stugusjøen, a similar development took place (Langeland 1981, 1988). Mysis relicta was introduced in 1973, and from 1978 the 3 most abundant planktonic cladocerans, Bosmina longispina, Daphnia galeata and Holopedium gibberum, were almost absent in the samples. From 1980, vertical hauls showed a mysid abundance of 30 to 100 ind. $\mathrm{m}^{-2}$. In 2 mysid-free neighbouring lakes, Lakes Møsjøen and Grønsjøen, no significant decrease in the zooplankton populations was recorded for the same period. These lakes have similar environmental conditions as Lake Stugusjøen, and the only fish species in all 3 lakes were Arctic char and brown trout. 
The cladoceran numbers decreased dramatically for a period of $10 \mathrm{yr}$ in Lille Jonsvatn, and the low abundance was considered permanent until the numbers again began to increase in 1995. In 1996, the mean biomass of cladocerans very surprisingly developed to the same level as before the collapse. Bosmina longispina was again the dominant species, followed by Holopedium gibberum and Daphnia galeata. The causes for the sudden return of cladocerans are unclear. Threlkeld et al. (1980) reported a reappearance of Bosmina in Lake Tahoe for a short period with low Mysis diluviana density. In the present study, mysid density in Lille Jonsvatn was low in 1996 and considerably lower than the 4 last years of the investigation (2003 to 2006). Unfortunately, M. relicta was not sampled in Lille Jonsvatn prior to 1996; however, from frequent occurrence in the plankton samples, the existence of the species in this part of the lake was well known. The new collapse of $B$. longispina and $H$. gibberum in 1998-1999 did not coincide with a recorded increase in $M$. relicta abundance, as the mysid density was extremely low in 1999. Interspecific competition with the rapidly increasing Daphnia populations may have played an important role for the reduction of $B$. longispina and $H$. gibberum. The Daphnia populations continued to increase until 2000, and afterwards varied considerably, with the highest mean density occurring in 2006, when the second highest density of $M$. relicta was recorded.

There is no coincidental long-term study of the development of planktivorous fish in Lake Jonsvatn. In 1999, however, a survey of the fish populations in Lille Jonsvatn, performed by series of floating and bottomset gill nets (10 to $45 \mathrm{~mm}$ mesh size), revealed that the population of Arctic char, the only planktivorous fish species, was very small (Koksvik 2000). Gut analysis showed that Mysis relicta, Daphnia galeata and D. longispina were the most important food items. Arctic char has also been found to prey extensively on $M$. relicta and cladocerans in Store Jonsvatn (Næsje et al. 1991). However, since Arctic char was reported by local fishermen to have been scarce in Lille Jonsvatn from pre-mysid years and up to the present, it is unlikely that this species was an important agent in the development of zooplankton and $M$. relicta in Lille Jonsvatn.

In 1998-1999, Daphnia galeata was replaced by $D$. longispina. This development is the opposite of what Rieman \& Falter (1981) reported from a study in Pend Oreille Lake in Idaho, where only the round-headed $D$. thorata was present before the introduction of mysids, whereas a pointed-helmet form, D. galeata mendotae, gained numerical dominance after the introduction. Summer forms of D. galeata in Lake Jonsvatn typically have pointed helmets, whereas D. longispina is round- headed. Protuberances such as spines and pointed helmets may be important in preventing predation from other invertebrates, and was discussed as a defence against mysid attacks in Pend Oreille Lake.

The ability of Daphnia longispina to develop and sustain a population at a relatively high biomass level in Lille Jonsvatn in the presence of the dense Mysis relicta population recorded in 2003-2006 is puzzling. Both $D$. longispina and D. galeata mainly inhabited the upper $10 \mathrm{~m}$ of the water column and the size of the 2 species was about equal. It is difficult to see what antipredator strategies D. longispina might have developed that made it more competitive and viable than $D$. galeata, and why Store Jonsvatnet or other mysid lakes in the same district have not experienced an equivalent development. In Store Jonsvatn, D. galeata was the strongly dominating daphnid through the entire investigation. In Lake Selbusjøen, D. longispina was more negatively affected than $D$. galeata (Langeland et al. 1991), and in Lake Stugusjøen D. galeata, the only daphnid in the lake, completely disappeared $5 \mathrm{yr}$ after the introduction of $M$. relicta (Langeland 1981).

In Lille Jonsvatn, the 10 yr period with extremely low cladoceran biomass may also have affected the dominant copepod species, Cyclops scutifer, which showed a significant biomass decrease. It is reasonable that the predation pressure by Mysis relicta became stronger on copepods when cladocerans were scarce or absent. When cladoceran abundance increased again from 1995 to 1996, C. scutifer did as well. The assumption that the decrease in C. scutifer was caused by mysid predation is supported by a study of Canadian lakes by Nero \& Sprules (1986b), where C. scutifer abundance was found to be much lower in 2 mysid lakes than in 2 similar lakes without mysids. Heterocope appendiculata and Arctodiaptomus laticeps decreased after $M$. relicta introduction in the nearby Lakes Selbusjøen (Langeland et al. 1991) and Stugusjøen (Langeland 1988), but in Lake Jonsvatn no such long-term trend was found, although both species have varied considerably within periods of a few years. Rybock (1978) reported a consistently negative selection for the copepod Diaptomus in Lake Tahoe.

Among the rotifers, Conochilus sp. strongly dominated the biomass in Lille Jonsvatn for the first years of the present study; however, it collapsed concurrently with the cladocerans and did not recover again. An equivalent development did not take place in Store Jonsvatn, where Conochilus sp. also was the dominant rotifer. It is plausible that Conochilus sp. was decimated by Mysis relicta predation in Lille Jonsvatn, although it might be a difficult prey as it forms colonies of considerable size. Rotifers have been paid less attention than cladocerans and copepods, but in some studies are reported to be part of the mysid diet 
(Lasenby \& Langford 1973, Bowers \& Grossnickle 1978, Johannsson et al. 2001, Ikonen et al. 2005). Lasenby \& Langford (1973) reported Kellicottia to be an important prey in Stony Lake, Ontario. Additionally, after the disappearance of Daphnia and Bosmina in Lake Tahoe in 1970-1971, densities of Kellicottia longispina varied inversely with estimates of $M$. diluviana, and gut analysis showed intensive use of Kellicottia as prey (Threlkeld et al. 1980). Rybock (1978) found positive selection for Kellicottia in Lake Tahoe and showed in an experiment that large $M$. diluviana were able to eat $3.5 \mathrm{~K}$. longispina per hour. Based on these studies, it seems reasonable that the decrease in K. longispina density in Lille Jonsvatn after 1984 also was a result of increased predation by $M$. relicta after the cladoceran collapse. The very low rotifer biomass in Lille Jonsvatn for the 10 last years of the investigation could be a combined effect of $M$. relicta predation and interspecific competition among the herbivorous zooplankton. An increase in abundance of large daphnids has led to a decrease in rotifers in other lakes in the region (Reinertsen et al. 1990, 1997), and is in accordance with the much debated size efficiency hypothesis (Brooks \& Dodson 1965).

The recorded cladoceran collapse in Lille Jonsvatn in 1985 was not clearly reflected in the development of algal biomass and composition during the grazing-free period 1985-1994. High maximum and mean annual algal biomasses were recorded in the years following 1985, but the decline in peak biomasses started from 1989 onwards, and mean biomass showed a significant decline from the late 1980 s, i.e. before the reappearance of the cladocerans in 1995-1996. Although phytoplankton may be an important part of the Mysis spp. diet (Grossnickle 1982, Johannsson et al. 2001), it has not been shown that $M$. relicta by its herbivory has influenced phytoplankton biomass in lakes. As the total P content in Lille Jonsvatn showed a significant decrease from $\sim 11 \mu \mathrm{g} \mathrm{l}^{-1}$ in $1989-1990$ to $5 \mathrm{\mu g} \mathrm{l}^{-1}$ in 2006 (Fig. 2), this may have been a major reason for the phytoplankton biomass decline. When comparing data from a large number of north temperate lake ecosystems, Mazumder (1994) found a strong positive response of algal biomass to total phosphorus in ecosystems where grazers are controlled by planktivores (odd-link ecosystems). The extremely low abundance of large cladocerans, the most important grazers, in Lille Jonsvatn from 1985 to 1995, indicates very strong planktivore control. It is also obvious that a change in grazing pressure after 1995, as indicated by the higher zooplankton (than phytoplankton) biomass (Fig. 10), affected the phytoplankton development in Lille Jonsvatn for the last $10 \mathrm{yr}$ of the present study. The ratio of herbivorous zooplankton to phytoplankton in most years after 1995 reflects an intensive grazing pressure, which is also shown by the significant increase in cryptophytes in the biomass share of rapidly growing algae, i.e. Rhodomonas lacustris (Fott 1975, Cronberg 1980, Reinertsen et al. 1990). Due to increased turnover rate of the phytoplankton, less biomass is produced per unit $\mathrm{P}$, as the $\mathrm{P}: \mathrm{C}$ ratio of algae increases with increasing growth rate (Olsen et al. 1983). The presence of gelatinous chlorophytes and cyanophytes also confirms a high grazing pressure (Porter 1977, Reinertsen 1982). A significant decrease in total $\mathrm{P}$ was also found in Store Jonsvatn in 1989-2006 (Fig. 2), but no change in total algal biomass or algal composition was recorded.

The sudden collapse in cladoceran populations recorded in Lille Jonsvatn did not take place in Store Jonsvatn, where attractive prey and mysids have coexisted for many years; however, there has been a longterm, slow decline in the density of the most attractive cladocerans. The decrease in cladoceran biomass in Store Jonsvatn has been less dramatic and taken considerably longer than in other lakes with introduced Mysis relicta in the same area. In Lakes Selbusjøen and Stugusjøen, the cladoceran populations were strongly reduced 5 to 6 yr after the mysid introduction (Langeland 1988, Langeland et al. 1991). No long-term trends in biomass change in copepod or rotifer species were detected in Store Jonsvatn.

The large differences in zooplankton development in the 2 basins of Lake Jonsvatn may be explained by differences in temperature and light conditions. In controlled laboratory experiments, Boscarino et al. (2007) found that Mysis diluviana preferred temperatures between 6 and $8^{\circ} \mathrm{C}$ and had limited movement into water of $12^{\circ} \mathrm{C}$ or higher. Martinez \& Bergersen (1991) found that temperatures above $14^{\circ} \mathrm{C}$ excluded $M$. diluviana from the epilimnion of Lake Granby, Colorado, and Rudstam et al. (1999) stated that mysids seldom occur in temperatures above $15^{\circ} \mathrm{C}$. Summer temperatures in the epilimnion normally exceed 14 to $15^{\circ} \mathrm{C}$ in all parts of Lake Jonsvatn. Due to a higher degree of wind exposure, the thermocline is often 1 to $2 \mathrm{~m}$ deeper in Store Jonsvatn than in Lille Jonsvatn. This might give the zooplankton a greater vertical refuge for population development in Store Jonsvatn. The duration of egg development in Daphniidae at $15^{\circ} \mathrm{C}$ is 5 to $7 \mathrm{~d}$ (Bottrell et al. 1976) and post-embryonic development (the time from hatching to attaining maturity) was, in an in situ experiment in Lake Haugatjern, not far from Lake Jonsvatn, 6 d at $13^{\circ} \mathrm{C}$ (Langeland et al. 1985). The period with sufficiently high temperatures to establish zooplankton refuges will normally last 1 to 2 mo in Lake Jonsvatn and provide enough time for development of several new generations. The larger refuge in Store Jonsvatn may be an important factor in explaining the differences in zooplankton development between the 2 basins. 
Differences in Secchi disc transparencies of 1 to $2 \mathrm{~m}$ show lower light transmission in Lille Jonsvatn than in Store Jonsvatn. This might result in acceptable light conditions for Mysis relicta to feed in the upper water layers for longer time periods at night in Lille Jonsvatn than in Store Jonsvatn in periods with acceptable temperatures $\left(<14\right.$ to $\left.15^{\circ} \mathrm{C}\right)$, and it may also contribute to a more sheltered environment for the zooplankton populations in the productive layers in Store Jonsvatn. Næsje et al. (2003) found that $90 \%$ of adult M. relicta stayed deeper than 49 to $53 \mathrm{~m}$ during light hours in May-September in Store Jonsvatn in a cool summer (maximum temperature $15^{\circ} \mathrm{C}$ at $1 \mathrm{~m}$ depth). Some juveniles $(<8 \mathrm{~mm})$ stayed 10 to $20 \mathrm{~m}$ higher up. During dark hours, both adults and juveniles performed vertical migrations and were found in all layers up to the surface. However, from mid-May to mid-July the nights are short at the high latitude of Lake Jonsvatn, and the period with acceptable light conditions for mysids to feed near the surface is quite limited. The shorter distance of vertical migration in Lille Jonsvatn (the maximum depth is $37 \mathrm{~m}$ and there are large areas with depths $\leq 30 \mathrm{~m}$ ) might also contribute to easier access for $M$. relicta to the zooplankton in the upper layers in this part of the lake.

The present long-term study in Lake Jonsvatn revealed an unexpected plankton development in both investigated basins. In Store Jonsvatn, the zooplankton biomass was unaffected for a longer time than in other regional lakes with introduced Mysis relicta, and the eventual decline in cladocerans was less pronounced. In Lille Jonsvatn, the mysid introduction was expected to give reduced negative effects due to the higher nutrient level in this part of the lake. However, the cladocerans collapsed almost totally in this basin. The most diverging result from earlier documentation of mysid impacts was the development of Daphnia longispina in Lille Jonsvatn after a depletion of cladocerans that had lasted for $10 \mathrm{yr}$. The documented ability of a large daphnid to develop and sustain a relatively high population density for years in the presence of a relatively high mysid abundance adds new knowledge to interactions in mysid lakes, and shows the importance of long-term studies.

Acknowledgements. Financial support was given by the Municipality of Trondheim, the Norwegian University of Science and Technology and the Norwegian Directorate for Nature Management.

\section{LITERATURE CITED}

Boscarino BT, Rudstam LG, Mata S, Gal G, Johannsson OE, Mills EL (2007) The effects of temperature and predator-prey interactions on the migration behaviour and vertical distribution of Mysis relicta. Limnol Oceanogr 52:1599-1613

Bottrell HH, Duncan A, Gliwicz ZM, Grygierek E and others (1976) Review of some problems in zooplankton production studies. Nor J Zool 24:419-456

Bowers JA, Grossnickle NE (1978) The herbivorous habits of Mysis relicta in Lake Michigan. Limnol Oceanogr 23: $767-776$

Bowers JA, Vanderploeg A (1982) In situ predatory behaviour of Mysis relicta in Lake Michigan. Hydrobiologia 93: 121-131

Branstrator DK, Cabana G, Mazumder A, Rasmussen JB (2000) Measuring life-history omnivory in the opossum shrimp, Mysis relicta, with stable nitrogen isotopes. Limnol Oceanogr 45:463-467

> Brooks JL, Dodson SI (1965) Predation, body size, and composition of plankton. Science 150:28-35

Cronberg G (1980) Phytoplankton changes in Lake Trummen induced by restoration. Longterm whole-lake studies and experimental biomanipulations. $\mathrm{PhD}$ thesis, University of Lund, Sweden

Fott J (1975) Seasonal succession of phytoplankton in the fish pond Smyslow near Blatnà, Czechoslovakia. Arch Hydrobiol 46(Suppl):259-279

Fürst M, Hammar J, Hill C, Boström U, Kinsten B (1984) Effekter av introduktion av Mysis relicta i reglerade sjöar i Sverige. Information från Sötvattenslaboratoriet, Drottningholm (in Swedish with English Abstract)

Grossnickle NE (1982) Feeding habits of Mysis relicta: an overview. Hydrobiologia 93:101-107

Ikonen S, Hakala I, Ojala A (2005) Seasonal and ontogenetic changes in food utilization of Mysis relicta. Verh Int Verein Theor Angew Limnol 29:764-767

Johannsson OE, Leggett MF, Rudstam LG, Servos MR and others (2001) Diet of Mysis relicta in Lake Ontario as revealed by stable isotope and gut content analysis. Can J Fish Aquat Sci 58:1975-1986

Kinsten B, Olsén P (1981) Impact of Mysis relicta Lòven introduction on the plankton of two mountain lakes, Sweden. Institute of Freshwater Research, Drottningholm, p 64-74

Koksvik J (2000) Prøvefiske i Lille Jonsvatn, Trondheim kommune. Vitenskapsmuseet Rapp Zool Ser 2000 1:1-21 (in Norwegian with English Abstract)

Koksvik JI, Reinertsen H, Langeland A (1991) Change in plankton biomass and species composition in Lake Jonsvatn, Norway, following the establishment of Mysis relicta. Am Fish Soc Symp 9:115-125

Langeland A (1981) Decreased zooplankton density in two Norwegian lakes caused by predation of recently introduced Mysis relicta. Verh Int Verein Theor Angew Limnol 21:926-937

Langeland A (1982) Interactions between zooplankton and fish in a fertilized lake. Holarct Ecol 5:273-310

Langeland A (1988) Decreased zooplankton density in a mountain lake resulting from predation by recently introduced Mysis relicta. Verh Int Verein Theor Angew Limnol 23:419-429

Langeland A, Koksvik JI, Olsen Y (1985) Post-embryonic development and growth rates of Daphnia pulex De Geer and Daphnia galeata Sars under natural food conditions. Verh Int Verein Theor Angew Limnol 22:3124-3130

Langeland A, Koksvik JI, Nydal J (1991) Impact of the introduction of Mysis relicta on the zooplankton and fish populations in a Norwegian Lake. Am Fish Soc Symp 9:98-114

Lasenby DC, Langford RR (1973) Feeding and assimilation of Mysis relicta. Limnol Oceanogr 18:280-285

Lasenby D, Shi YQ (2004) Changes in the elemental composi- 
tion of the stomach contents of the opossum shrimp Mysis relicta during diel vertical migration. Can J Zool 82: 525-528

Lasenby DC, Northcote TG, Fürst M (1986) Theory, practice and effects of Mysis relicta introductions to North American and Scandinavian lakes. Can J Fish Aquat Sci 43: $1277-1284$

Martinez PJ, Bergersen EP (1991) Interactions of zooplankton, Mysis relicta, and kokanees in Lake Granby, Colorado. Am Fish Soc Symp 9:49-64

Mazumder A (1994) Patterns of algal biomass in dominant odd- vs. even-link lake ecosystems. Ecology 75:1141-1149

Næsje TF, Jensen AJ, Moen V, Saksgard R (1991) Habitat use by zooplankton, Mysis relicta, and Arctic char in Lake Jonsvatn, Norway. Am Fish Soc Symp 9:75-87

Næsje TF, Saksgard R, Jensen AJ, Sandlund OT (2003) Life history, habitat utilisation, and biomass of introduced Mysis relicta. Limnologica 33:244-257

Nero RW, Sprules WG (1986a) Predation by three glacial opportunists on natural zooplankton communities. Can J Zool 64:57-64

Nero RW, Sprules WG (1986b) Zooplankton species abundance and biomass in relation to occurrence of Mysis relicta (Malacostraca: Mysidacea). Can J Fish Aquat Sci 43:420-434

Nesler TP, Bergersen EP (1991) Mysids and their impacts on fisheries: an introduction to the 1998 Mysid Fisheries Symposium. Am Fish Soc Symp 9:1-4

Olsen Y, Jensen A, Reinertsen H, Rugstad B (1983) Comparison of different algal carbon estimates by use of the Droop-model for nutrient limited growth. J Plankton Res 5:43-51

Porter KG (1977) The plant-animal interface in freshwater ecosystems. Am Sci 65:159-170

Reinertsen H (1982) The effect of nutrient addition on the

Submitted: April 2, 2008; Accepted: April 7, 2009 phytoplankton community of an oligotrophic lake. Holarct Ecol 5:225-252

Reinertsen H, Jensen A, Koksvik JI, Langeland A, Olsen Y (1990) Effects of fish removal on the limnetic ecosystem of a eutrophic lake. Can J Fish Aquat Sci 47:166-173

Reinertsen H, Koksvik JI, Haug A (1997) Effects of fish elimination on the phytoplankton and zooplankton in a small eutrophic lake. Verh Int Verein Theor Angew Limnol 26: 593-598

Richards RC, Goldman CR, Frantz TC, Wickwire R (1975) Where have all the Daphnia gone? The decline of a major cladoceran in Lake Tahoe, California-Nevada. Verh Int Verein Theor Angew Limnol 19:835-842

Rieman BE, Falter CM (1981) Effects of the establishment of Mysis relicta on the macrozooplankton of a large lake. Trans Am Fish Soc 110:613-620

Rudstam LG, Hetherington AL, Mohammadian AM (1999) Effect of temperature on feeding and survival of Mysis relicta. J Gt Lakes Res 25:363-371

Rybock JT (1978) Mysis relicta Lòven in Lake Tahoe: vertical distribution and nocturnal predation. $\mathrm{PhD}$ dissertation, University of California, Davis, CA

Scharf J, Koschel R (2005) Food composition and selectivity of Mysis relicta (Lòven) in Lake Breiter Luzin. Verh Int Verein Theor Angew Limnol 29:208-211

Spencer CN, Potter DS, Bukantis RT, Stanford JA (1999) Impact of predation by Mysis relicta on zooplankton in Flathead Lake, Montana, USA. J Plankton Res 21:51-64

Threlkeld ST, Rybock JT, Morgan MD, Folt CL, Goldman CR (1980) The effects of an introduced invertebrate predator and food resource variation on zooplankton dynamics in an ultraoligotrophic lake. In: Kerfoot WC (ed) Evolution and ecology of zooplankton dynamics in an ultraoligotrophic lake. University Press of New England, Hanover, $\mathrm{NH}, \mathrm{p} 555-568$

Proofs received from author(s): May 24, 2009 